\section{Cytotoxicity Profile of Endodontic Sealers Provided by 3D Cell Culture Experimental Model}

Emmanuel João Nogueira Leal Silva ${ }^{1}$, Nancy Kudsi de Carvalho ${ }^{1}$, Carina Taboada Ronconi1, Gustavo De-Deus ${ }^{1}$, Mario Luis Zuolo2, Alexandre Augusto Zaia²
'Department of Endodontics, Health Sciences Center, UNIGRANRIO

- Universidade Grande Rio, Rio de Janeiro, RJ, Brazil

2Department of Endodontics, Piracicaba Dental School, UNICAMP

- Universidade Estadual de

Campinas, Piracicaba, SP, Brazil

Correspondence: Emmanuel João Nogueira Leal Silva, Rua Herotides de Oliveira, 61/902, Icaraí, 24230230 Niterói, RJ, Brasil. Tel: +5521-98357-5757. e-mail address: nogueiraemmanuel@hotmail.com
The aim of the present study was to evaluate the cytotoxic effects of five endodontic sealers (AH Plus, Endomethasone N, EndoSequence BC, MTA Fillapex and Pulp Canal Sealer EWT) using a three-dimensional (3D) cell culture model. A conventional bi-dimensional (2D) cell culture model was used as reference technique for comparison. Balb/c 3T3 fibroblasts were cultured in conventional bi-dimensional cell culture and in rat-tail collagen type I three-dimensional cell culture models. Then, both cell cultures were incubated with elutes of freshly mixed endodontic sealers for $24 \mathrm{~h}$. Cell viability was measured by the methyl-thiazol-diphenyltetrazolium assay (MTT). Data were statistically analyzed using ANOVA and the Tukey test at a significance level of $p<0.05$. All tested sealers exhibited cytotoxic effects; however, cytotoxic effect was culture model- and sealer-dependent. Sealers showed higher cytotoxicity in 2D than in 3D cell culture model $(p<0.05)$. In both conditions, EndoSequence BC showed the lowest cytotoxicity $(p<0.05)$. MTA Fillapex was much more cytotoxic than the other tested endodontic sealers $(p<0.05)$, with the exception of AH Plus in the 2D cell culture model ( $p>0.05)$. Endomethasone $N$ and Pulp Canal Sealer EWT showed lower cytotoxic effects than AH Plus in 2D cell culture model $(p<0.05)$; however no statistical differences was observed among these sealers in 3D cell culture model. It may be concluded that cytotoxicity was higher in 2D cell culture compared to 3D cell culture. EndoSequence BC sealer exhibited the highest cytocompatibility and MTA Fillapex the lowest cytocompatibility.
Key Words: root canal sealers, cytotoxicity, 3D cell culture.

\section{Introduction}

Root canal sealers may come in intimate contact with the periapical tissues for an extended period because of extrusion from the apex and/or when restricted to the root canal because of degradation products that may leach through a lateral and accessory canal or apical foramina, reaching the surrounding tissues (1-3).

Thus, for safety reasons, each sealer must have its biological properties comprehensively and independently screened by in vitro and in vivo tests before its unlimited clinical use, in order to minimize incidence of local and/or systemic adverse effects (4-6). From a clinical point of view, there are clear limitations to the correlation between in vitro data and clinical behavior. However, in vitro cytotoxicity tests are important for understanding the biologic risks of these materials, mainly at the initial setting stage (7).

Generally, cytotoxicity tests are evaluated using traditional bi-dimensional (2D) culture systems. It may be argued that although some sealers have a significant toxic behavior in vitro, it does not occur in the clinical real-life situation mostly because of the difference between in vitro and in vivo conditions. Bi-dimensional culture systems form a monolayer that may have inhibition contacts among cells and change the original characteristic of cell morphology and functionality (8). Three-dimensional (3D) cell models, on the other hand, can mimic in vivo cellular conditions in a better way because the 3D scaffold supports cell growth and cell functions, including morphogenesis, cell metabolism and cell-to-cell interactions (9).

Some of the most widely used sealers are based on zinc-oxide eugenol (Endomethasone $\mathrm{N}$ and Pulp Canal Sealer EWT), epoxy resin (AH Plus) and calcium silicate (EndoSequence BC and MTA Fillapex). They exhibit a variable degree of cytotoxicity depending on the conditions under which the test was performed (10-15). Biocompatibility of endodontic sealers is determined by several parameters, like composition of leachable components, setting characteristics, stability of the set material and size of the contact area between the sealers and the adjacent tissues (10-15). Whereas the 2D cytotoxicity of these endodontic sealers is well documented (10-15), no study evaluated their 3 D cytotoxicity. Therefore, the aim of the present study was to evaluate the cytotoxic effects of these five endodontic sealers using a $3 \mathrm{D}$ cell culture model. A conventional 2D cell culture model was used as a reference method for 
comparison. The tested hypotheses were: 1 .There are no differences in cytotoxicity when using conventional 2D and $3 \mathrm{D}$ cell culture experimental models; 2 . The tested sealers display similar cytotoxic patterns.

\section{Material and Methods}

\section{Test Materials}

Five root canal sealers were evaluated: AH plus (Dentsply, Konstanz, Germany), Endomethasone N (Septodont, Saint Maur des Fosses, France), EndoSequence BC (Brasseler, Savannah, GA, USA), MTA Fillapex (Angelus, Londrina, PR, Brazil) and Pulp Canal Sealer EWT (SybronEndo, Orange, CA, USA). The materials, product names, manufactures and components are listed in Table 1. The sealers were mixed according to the manufacturers' instructions. Discs containing the materials were fabricated under aseptic conditions in sterile nonreactive plastic molds with 5 $\mathrm{mm}$ diameter and $2 \mathrm{~mm}$ height. Excess flash material was removed with a sterile scalpel. The experiment was designed to test endodontic sealers immediately after mixing. The extraction was made in cell culture medium using a surface-area-to-volume ratio of approximately 150 $\mathrm{mm}^{2} / \mathrm{mL}$ between the sample surface and the volume of the medium (16). The extraction vials were agitated for $24 \mathrm{~h}$ in a water bath at $37^{\circ} \mathrm{C}$. The control samples containing only culture medium were treated similarly. Undiluted extracts were used for the tests.

\section{Cell Line}

Balb/c 3T3 cells fibroblasts (American Tissue Type Collection; ATCC, Manassas, VA, USA) were cultured in Dulbecco's Modified Eagle Medium (DMEM) (Gibco, Grand Island, NY, USA) supplemented with 10\% fetal bovine serum (FBS) (Sigma Chemical Co, St Louis, MO USA), 100 $\mu \mathrm{g} / \mathrm{mL}$ of streptomycin, $100 \mathrm{mg} / \mathrm{mL}$ of penicillin at $37^{\circ} \mathrm{C}$ in a humidified incubator under room pressure atmosphere containing $5 \% \mathrm{CO}_{2}$. When the cells attained confluence, trypsin/ethylenediaminetetraacetic solution (Sigma) was used to split.

\section{Cell Cultures}

For the monolayer (2D) culture, cells were seeded in 6 -well plates $\left(3 \times 10^{5}\right.$ cells/well). After overnight attachment, cells were treated with $1 \mathrm{~mL}$ extract of the test material by medium change and were cultured for another $24 \mathrm{~h}$. DMEM was used as the control group (5).

For the 3D cell culture, the culture surface was prechilled and then pre-coated with a thin layer of rat tail collagen type I (Gibco). In order to obtain a final concentration of $1 \mathrm{mg} / \mathrm{mL}$, the volume of required collagen was neutralized with $0.1 \mathrm{M} \mathrm{NaOH}$ and $10 \mathrm{x}$ medium using the following equations:

$$
\begin{gathered}
V_{\mathrm{NaOH}}=0.06 \times V_{\text {collagen }} ; \quad V_{10 X}=V_{\text {final }} \times 0.1 ; \quad V_{\text {medium }} \\
=V_{\text {final }}-V_{\text {collagen }}-V_{N a O H}-V_{10 X}
\end{gathered}
$$

The cells were trypsinized from a monolayer to a singlecell suspension. Then cells $\left(3 \times 10^{5} \mathrm{cell} / \mathrm{s} / \mathrm{mL}\right)$ from $2 \mathrm{D}$ culture were mixed with the chilled collagen solution. The proper volume of the mixture of cells and collagen was added onto the pre-coated surface and immediately transferred to a $37{ }^{\circ} \mathrm{C}$ incubator for $20 \mathrm{~min}$ to allow polymerization of the collagen. After formation of the collagen gel, $1 \mathrm{~mL}$ of DMEM was added. Cells have grown in 3D collagen for 7 days. The medium was changed daily. After 7 days, cells were treated with $1 \mathrm{~mL}$ extract of test material by medium

Table 1. Composition of materials and their manufacturers

Root Canal Sealer Components

AH Plus, Dentsply, Germany

Endomethasone N, Septodont, France

EndoSequence BC, Brasseler, USA

MTA Fillapex, Angelus, Brazil

Pulp Canal Sealer EWT, SybronEndo, USA
Paste A: Epoxy resins, calcium tungstate, zirconium oxide, silica, iron oxide pigments, Aerosil Paste B: Adamantane amine, N,N-Dibenzyl-5-oxanonane, TCDdiamine, calcium tungstate, zirconium oxide, Aerosil

Powder: hydrocortisone acetate, thymol iodide, barium sulphate, zinc oxide, magnesium stearate Liquid: Eugenol

Zirconium oxide, calcium silicates, calcium phospate monobasic, calcium hydroxide, filler and thickening agents

Salicylate resin, diluting resin, natural resin, bismuth trioxide, nanoparticulated silica, MTA, pigments 
change and were cultured for another $24 \mathrm{~h}$. Pure DMEM was also used as the control group (1).

Ten replicates of each extract and control were analyzed in each cell culture method.

\section{Cytotoxicity Analysis}

The cytotoxicity of endodontic sealers in the 2D and 3D cultures was determined using the 3-(4,5-dimethylthiazol2-yl)-2,5-diphenyltetrazolium bromide (MTT) assay. After removal of the culture medium from each well, the cells were gently washed with $1.0 \mathrm{~mL}$ phosphate-buffered saline. The wash was replaced with an MT-succinate solution ( $1 \mathrm{mg} / \mathrm{mL}$; Sigma-Aldrich, St Louis, MO, USA) for $4 \mathrm{~h}$. The blue formazan precipitate was extracted from the mitochondria using dimethyl sulfoxide on a shaker at room temperature for $30 \mathrm{~min}$. Three aliquots $(100 \mu \mathrm{L})$ of the solution were then transferred from each well to a 96-well plate and the absorbance measured at $490 \mathrm{~nm}$ by a microplate reader (Urit 660; Urit, Guillin Guanxi, China). The formazan content of each well was computed as a percentage of the control group.

\section{Statistical Analysis}

The preliminary analysis of the data revealed a normal distribution (Kolmogorov-Smirnov normality test). Therefore, data were analyzed using one-way analysis of variance (ANOVA). Statistical differences amongst the groups were analyzed using the Tukey's test at a significance level of 5\% (SPSS 17.0; SPSS Inc, Chicago, IL, USA).

\section{Results}

In all test conditions, the tested sealers exhibited cytotoxic effects; however, cytotoxic effect was culture model- and sealer-dependent. Sealers showed high cytotoxic effects in the $2 \mathrm{D}$ cell culture model compared to the $3 \mathrm{D}$ cell culture model $(p<0.05)$. In both conditions, EndoSequence $B C$ showed the lowest cytotoxicity $(p<0.05)$. In contrast, MTA Fillapex was more cytotoxic than the other tested endodontic sealers $(p<0.05)$, with the exception of AH Plus in the 2D cell culture model ( $p>0.05$ ). Endomethasone $N$ and Pulp Canal Sealer EWT showed lower cytotoxic effects than AH Plus in 2D cell culture model $(p<0.05)$; however no statistical differences were observed among these sealers in 3D cell culture model. Cytotoxicity data are in Figure 1.

\section{Discussion}

The obtained results showed that cytotoxicity of endodontic sealers in the conventional 2D cell culture model was significantly higher than in the 3D cell culture model. This means that the cytotoxicity of sealers was dependent of the experimental model. Therefore, the first tested hypothesis was rejected. At the cell level, several studies have shown that endodontic sealers may be cytotoxic to specific cell types in vitro and in vivo (10,12-15). Extensive studies have shown that these sealers can induce cytotoxicity using a 2D cell culture model $(10,12-15)$; however, to the best of the authors' knowledge, this is the first attempt to evaluate the cytotoxicity of these endodontic sealers by a 3D cell culture model. Additionally, a direct comparison among 2D and 3D cell culture models was also provided.

The cytotoxicity potential of dental materials is commonly assessed using 2D cell monolayer structures, which is in line with the International Organization for Standardization (ISO 10993-5) (16). In comparison with the traditional 2D cell culture model, which is considered the simplest model devoid of most in vivo characteristics, the $3 \mathrm{D}$ cell culture model seems to be a more physiologically relevant and predictive model $(17,20)$. The $2 \mathrm{D}$ cell monolayer structures bear little physical resemblance to the complex $3 \mathrm{D}$ tissues (18), leading to increased toxin susceptibility (19) and unsuitable immune reactions (20), thereby limiting their clinical application and relevance. Moreover, 3D cell cultures have greater stability and longer life spans than cell cultures in 2D (21). This means that they are more suitable for long-term studies and for demonstrating longterm effects of the drug. Currently, all 2D culture-based toxicity tests must undergo regular trypsinization due to continuous cell growth. However, further toxicity tests are

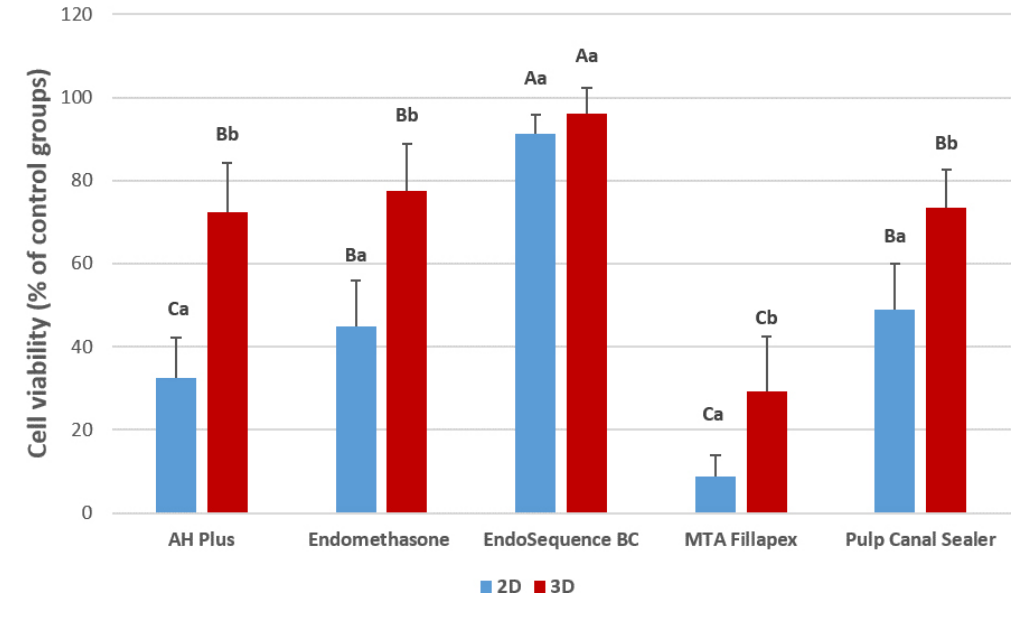

Figure 1. Quantitative comparison of cytotoxicity assays between 2D and 3D cell cultures after endodontic sealers exposure. Results are expressed as mean and standard deviation. Different capital letters represent statistical differences between sealers in the same cell culture model $(\mathrm{p}<0.05)$. Different lowercase letters represent statistical differences of the same sealer in different cell culture models $(\mathrm{p}<0.05)$. 
required to understand how toxic molecules affect cellular behavior in chronic exposure to toxic substances.

The different cytotoxicity responses of 2D and 3D cell models presented here are most likely associated with the addition of the third dimension to the cell culture models and the extensive cell-cell interactions occurring in the 3D cell aggregates. In addition, some intrinsic limitations of the in vitro cell culture model, including the methods of exposing cells, do not allow accurate reproduction of the physiological conditions in vivo. The different toxicity thresholds between the 2D and 3D cell models may also be associated with a decreased capability of sealer extracts to penetrate within the 3D cell aggregates.

According to the present results, MTA Fillapex showed higher cytotoxicity in 2D and 3D models compared to the other tested sealers. Therefore, the second hypothesis was rejected. These findings agree with previous $2 \mathrm{D}$ studies that showed strongly affected cell viability with MTA Fillapex $(10,14)$. A possible explanation for these results is the presence of toxic components such as salicylate resin, diluted resin and silica in MTA Fillapex composition. Moreover, the high solubility of MTA Fillapex may account for a greater amount of toxic sealer components release during the elution in DMEM, resulting in a higher exposition of MTA Fillapex to cell culture. In contrast, EndoSequence $\mathrm{BC}$, another calcium silicate-based sealer, showed excellent biocompatibility. This indicates the different influence of constituent components other than calcium silicate on the cytotoxicity of the sealers. The manufacturer claims that EndoSequence $\mathrm{BC}$ sealer is a bioceramic material, a ceramic product or component with osteoinductive properties used in medical and dental applications. The results of the present study agree with previous studies, which also demonstrated low cytotoxicity of EndoSequence BC sealer $(22,23)$.

Endomethasone N and Pulp Canal Sealer EWT are zinc oxide-eugenol root canal sealers that showed moderate cytotoxicity results. This toxicity may be ascribed to the free eugenol release by the materials. Eugenol has been reported as the major cytotoxic component in zinc oxide-eugenol root canal sealers (24). It is important to emphasize that the Endomethasone $\mathrm{N}$ is a new formulation of Endomethase and is "formaldehyde free", according to the manufacturer. Therefore, it is not possible to associate this component with the toxic effects of this sealer. The exact cytotoxicity mechanism of AH Plus is unclear; however, it is believed that the formaldehyde release by epoxy resin, the release of bisphenol A diglycidyl ether and the amine reaction to initiate the polymerization may explain the toxicity of AH Plus (25).

With all the exposed data, it is clear that the cell culture model plays an important role in the biological effects of endodontic sealers. The present results strongly indicate that cell culture may be used as an alternative in vitro experimental model able to provide reliable guidance on endodontic sealers' toxicity under conditions more closely related to the physiological scenario found in real-life 3D tissue microenvironments.

It may be concluded that cytotoxicity was higher in 2D cell culture compared to 3D cell culture. Moreover, EndoSequence BC sealer exhibited the highest cytocompatibility and MTA Fillapex the lowest.

\section{Resumo}

0 objetivo do presente estudo foi avaliar os efeitos citotóxicos de cinco cimentos endodônticos (AH Plus, Endomethasone N, EndoSequence BC, MTA Fillapex e Pulp Canal Sealer EWT) utilizando um modelo de cultura celular tridimensional (3D). Utilizou-se um modelo convencional de cultura de células bidimensionais (2D) como técnica de referência para comparação. Os fibroblastos Balb/c 3T3 foram cultivados em culturas de células bidimensionais convencionais e em modelos de cultura de células tridimensionais de colagéno de cauda de rato do tipo I. Em seguida, ambas as culturas de células foram incubadas com eluções dos cimentos endodônticos recém manipulados, durante $24 \mathrm{~h}$. A viabilidade celular foi medida pelo ensaio de MTT. Os dados foram analisados estatisticamente utilizando ANOVA e o teste de Tukey com nivel de significância de $p<0,05$. Todos os cimentos testados exibiram efeitos citotóxicos. Contudo, o efeito citotóxico foi dependente do modelo de cultura e do cimento testado. Os cimentos apresentaram maior citotoxicidade no modelo $2 \mathrm{D}$ do que no modelo 3D $(p<0,05)$. Em ambas as condições, a EndoSequence $B C$ apresentou a menor citotoxicidade $(p<0,05)$. MTA Fillapex foi mais citotóxico do que os outros cimentos endodônticos testados $(p<0,05)$, com exceção do AH Plus no modelo de cultura de células $2 D(p>0,05)$. Endomethasone N e EWT mostraram efeitos citotóxicos mais baixos do que AH Plus no modelo de cultura de células $2 \mathrm{D}(\mathrm{p}<0,05)$; entretanto, não houve diferenças estatisticas entre esses cimentos no modelo de cultura de células 3D. Pode concluir-se que a citotoxicidade foi maior na cultura de células 2D em comparação com a cultura de células 3D. EndoSequence BC selante exibiu a maior citocompatibilidade e MTA Fillapex a menor citocompatibilidade.

\section{Acknowledgements}

The authors deny any conflict of interest. This study was partially funded by FAPERJ grants E-26/010.001243/2015 and E-26/201.491/2014.

\section{References}

1. Holland $R$, Sant'Anna Junior $A$, Souza $V$, Dezan Junior $E$, Otoboni Filho $J A$, Bernabe PF, et al.. Influence of apical patency and filling material on healing process of dogs' teeth with vital pulp after root canal therapy. Braz Dent J 2005;16:9-16.

2. Yamaguchi K, Matsunaga T, Hayashi Y. Gross extrusion of endodontic obturation materials into maxillary sinus: a case report. Oral Surg Oral Med Oral Pathol Oral Radiol Endod 2007;104:131-134.

3. Bernath $M$, Szabo J. Tissue reaction initiated by different sealers. Int Endod J 2003;36:256-261.

4. Schwarze T, Fiedler I, Leyhausen G, Geurtsen W. The cellular compatibility of five endodontic sealers during the setting period. J Endod 2002;28:784-786.

5. Silva EJ, Accorsi-Mendonça T, Almeida JF, Ferraz CC, Gomes BP, Zaia AA. Evaluation of cytotoxicity and up-regulation of gelatinases in human fibroblast cells by four root canal sealers. Int Endod J 2012;45:49-56.

6. Geurtsen W. Biocompatibility of root canal filling materials. Aust Endod J 2001;27:12-21.

7. Ergun G, Egilmez F, Uctasli MB, Yilmaz S. Effect of light curing type on cytotoxicity of dentin-bonding agents. Int Endod J 2007;40:216-23. 
8. Mueller-Klieser W. Three-dimensional cell cultures: from molecular mechanisms to clinical applications. Am J Physiol 1997;273:1109-1123.

9. Carletti $E$, Motta A, Migliaresi C. Scaffolds for tissue engineering and 3D cell culture. Methods Mol Biol 2011;695:17-39.

10. Silva EJ, Rosa TP, Herrera DR, Jacinto RC, Gomes BP, Zaia AA. Evaluation of cytotoxicity and physicochemical properties of calcium silicatebased endodontic sealer MTA Fillapex. J Endod 2013;39:274-277.

11. Trichês KM, Júnior JS, Calixto JB, Machado R, Rosa TP, Silva EJ, et al.. Connective tissue reaction of rats to a new zinc-oxide-eugenol endodontic sealer. Microsc Res Tech 2013;76:1292-1296.

12. Cotti E, Petreucic V, Re D, Simbula G. Cytotoxicity evaluation of a new resin-based hybrid root canal sealer: an in vitro study. J Endod 2014;40:124-128.

13. Scelza MZ, Linhares $A B$, Silva LE, Granjeiro JM, Alves GG. A multiparametric assay to compare the cytotoxicity of endodontic sealers with primary human osteoblasts. Int Endod J 2012;45:12-18.

14. Silva EJ, Santos CC, Zaia AA. Long-term cytotoxic effects of contemporary root canal sealers. J Appl Oral Sci 2013;21:43-47.

15. Camargo CH, Oliveira TR, Silva GO, Rabelo SB, Valera MC, Cavalcanti BN. Setting time affects in vitro biological properties of root canal sealers . J Endod 2014;40:530-533.

16. International Organization for Standardization ISO 10993 Biological Evaluation of Medical Devices - Part 5: Tests for in vitro cytotoxicity. Geneva, Switzerland: International Organization for Standardization; 2009.

17. Silva EJ, Carvalho NK, Zaia AA. Cytotoxic profile of epoxy resin provided by a new experimental 3D cell culture model. ENDO 2016;10:9-13.

18. Bokhari M, Carnachan RJ, Cameron NR, Przyborski SA. Novel cell culture device enabling three-dimensional cell growth and improved cell function. Biochem Biophys Res Commun 2007;354:1095-1100.

19. Groeber F, Holeiter M, Hampel M, Hinderer S, Schenke-Layland K. Skintissue engineering - in vivo and in vitro applications. Adv Drug Deliv Rev 2011;30:352-366.

20. Wataha JC, Nakajima H, Hanks CT, Okabe T. Correlation of cytotoxicity with element release from mercury- and gallium-based dental alloys in vitro. Dent Mater 1994;10:298-303.

21. Wrzesinski K, Magnone MC, Hansen LV, Kruse ME, Bargauer T, Bobadilla $\mathrm{M}$ et al.. HepG2/C3A spheroids exhibit stable physiological functionality for at least 24 days after recovering from trypsinisation. Toxicol Res 2013;2:163-172.

22. Zhou HM, Du TF, Shen Y, Wang ZJ, Zheng YF, Haapasalo M. In vitro cytotoxicity of calcium silicate-containing endodontic sealers. J Endod 2015;41:56-61.

23. Zoufan $K$, Jiang J, Komabayashi $T$, Wang $Y H$, Safavi $K E$, Zhu 0 . Cytotoxicity evaluation of Gutta Flow and Endo Sequence BC sealers. Oral Surg Oral Med Oral Pathol Oral Radiol Endod 2011;112:657-661.

24. Chang MC, Lin LD, Chen YJ, Tsai YL, Cheng YA, Kuo CS, et al.. Comparative cytotoxicity of five root canal sealers on cultured human periodontal ligament fibroblasts. Int Endod J 2010;43:251-257.

25. Miletic I, Devcic N, Anie I, Borcic J, Karlovic Z, Osmac M. The cytotoxicity of RoekoSeal and AH Plus compared during different setting periods. J Endod 2005;32:307-309. 